\title{
Lateral Migration in a Wandering Reach of the Middle Yellow River in Response to Different Boundary Conditions
}

\author{
Jie $\mathrm{Li}^{1, *}$, Yi Zhang ${ }^{2}$ and Qingfeng Ji ${ }^{1}$ \\ 1 College of Hydraulic Science and Engineering, Yangzhou University, Yangzhou 225009, China; \\ qfji@yzu.edu.cn \\ 2 Jiangsu Surveying and Design Institute of Water Resources Co., Ltd., Yangzhou 225009, China; \\ zhangyi0224@whu.edu.cn \\ * Correspondence: lij2010@whu.edu.cn; Tel.: +86-187-0719-9190
}

Received: 29 June 2020; Accepted: 27 July 2020; Published: 29 July 2020

\begin{abstract}
The Xiaobeiganliu reach is a typical wandering reach of the Middle Yellow River that has rapid and significant channel lateral migration, which may threaten the safety of riparian land and flood control structures. To investigate the characteristics and mechanism of lateral migration in the Xiaobeiganliu reach, the temporal and spatial variations in bankfull width and thalweg migration distance were identified during the continuous deposition period, quantitatively analyzing the effect of different boundary conditions on the lateral migration index. The reach-scale bankfull width decreased by 32\% from 1986 to 2001 because hyperconcentrated floods often occurred in this reach. The thalweg migration distance varied dramatically at cross-sections, with the maximum annual thalweg migration distance reaching $4290 \mathrm{~m}$. The lateral migration index of the Xiaobeiganliu reach responded well to the upstream and downstream boundary conditions. The previous 3-year average water discharge and 4-year average sediment concentration at the upstream station were two key fluvial factors influencing lateral migration, with the relation being established between the lateral migration index and the two parameters. The Tongguan (TG) elevation was the key downstream boundary condition affecting thalweg migration, and a power function was proposed between the lateral migration index and the variations in annual TG elevation.
\end{abstract}

Keywords: lateral migration; wandering reach; boundary conditions; Middle Yellow River

\section{Introduction}

Channel lateral migration is a morphodynamic adjustment that has been extensively documented in various rivers worldwide [1-5]. Lateral migration plays a crucial role in the functioning of aquatic and riverine ecosystems, and reduced lateral migration usually leads to a decrease in habitat quality [6-8]. Therefore, the restoration and preservation of river environments usually require a mobile channel $[9,10]$. On the other hand, severe channel lateral migration may threaten the safety of flood control structures and human property, a topic that has attracted great attention from scientists in the context of river engineering and fluvial management [11-14].

Lateral migration in alluvial rivers generally covers channel width adjustments, thalweg migration, shifting of the main channel, and meander migration. The thalweg is the line of lowest bed elevation within the watercourse [2]. Large-scale shifting of the main channel can lead to severe thalweg migration, and thalweg migration rates usually exceed the magnitude of the main channel shifting [15]. Various methods have been used to determine the magnitude of channel lateral migration in recent years, including analysis of measured cross-sectional profiles, remote sensing techniques, and mathematical models [4,16-19]. For example, Xia et al. [16] investigated the changes in bankfull width in a braided 
reach after the operation of a large reservoir based on annual measured cross-sectional profiles, which indicated that bankfull width increased greatly owing to severe bank erosion. Debnath et al. [4] analyzed the characteristics of channel width, radius of curvature, and sinuosity index using Remote Sense (RS) and Geographic Information System (GIS) in the Khowai River, with the relationship between channel migration and land use being discovered. Sun et al. [19] developed a morphological mathematical model to simulate the processes of bank failure and bed deformation, and the results showed that the effect of secondary flow played an important part in channel migration. Analysis of measured cross-sectional profiles can accurately show the variations in channel migration, which is a common method to investigate fluvial processes of alluvial rivers. Remote sensing techniques can acquire a wide range of data, but the precision is often affected by weather, such as clouds and snow. Mathematical models can simulate the processes of channel width changes and thalweg migration, but it usually needs detailed information including bed material composition and bank soil properties.

Fluvial processes in alluvial rivers are generally influenced by various boundary conditions, including upstream boundary conditions, downstream boundary conditions, and other boundary conditions $[20,21]$. The upstream boundary conditions usually refer to the incoming flow and sediment regime, which are considered to be the main factors influencing channel evolution. Some studies have been conducted to investigate the effect of upstream boundary conditions on channel lateral migration [5,9,11,22,23]. For example, Richard et al. [11] investigated the lateral movement of the Rio Grande in New Mexico and found that channel migration rates primarily increased with an increase in flow energy based on statistical analysis. Li et al. [5] investigated the variation in thalweg migration intensity in a braided reach of the Lower Yellow River in 1986-2015 and established a relation between thalweg migration intensity and the previous 4-year average fluvial erosion intensity. Wang et al. [23] determined the migration rates of the main channel in a wandering reach and found that fluvial factors were the key factors influencing the migration rates. The downstream boundary conditions generally refer to changes in the local base level, which is regarded as an imaginary horizontal level or surface where channel erosion proceeds [20]. Several studies have shown that base level changes can significantly influence channel adjustments in alluvial rivers [24-28]. Edwards et al. [25] found that the mean bankfull width in the lower White River increased by $21 \%$ following base-level lowering from 1930 to 2010. Vachtman and Laronne [26] suggested that a base level drop initially led to channel incision followed by channel widening in cohesive channels. Lin et al. [27] calculated channel bankfull dimensions in the Jinjiang reach of the Middle Yangtze River and developed empirical relations between bankfull dimensions and downstream controls. In addition, other boundary conditions, such as bed and bank materials and riparian vegetation, can affect channel lateral migration $[16,29,30]$. The channel planform geometry, including width, radius of curvature and sinuosity, was also associated with the magnitude of channel migration [13,31].

The Xiaobeiganliu reach is a typical wandering reach in the Middle Yellow River, and it has a very wide and shallow channel. This reach is very famous for channel lateral migration, and it is reported that the maximum magnitude of lateral migration can reach up to $14.8 \mathrm{~km}$ in one year [32]. Previous studies paid little attention to the characteristics of channel migration in this wandering reach, and the effect of incoming flow and sediment regime, base level changes, and other factors on thalweg migration were poorly understood. The main purposes of this paper are (i) to investigate the temporal and spatial variations in bankfull width and thalweg migration distance in the Xiaobeiganliu reach of the Middle Yellow River during the period from 1986 to 2001; (ii) to quantitatively determine the effects of different boundary conditions on channel lateral migration in the Xiaobenganliu reach and find the dominant factor influencing the lateral migration index. The results of the current study can facilitate a better understanding of the characteristics and mechanism of channel migration in wandering rivers. The relationships between lateral migration index and influencing factors can be established to predict channel migration processes in the Xiaobeiganliu reach, which is helpful for flood control and river channel management. 


\section{Study Area and Data Collection}

\subsection{Study Area}

The Xiaobeiganliu reach spans from Longmen (LM) to Tongguan (TG) in the Middle Yellow River, which is located between $110^{\circ} 15^{\prime}-110^{\circ} 38^{\prime}$ E longitude and $34^{\circ} 35^{\prime}-35^{\circ} 49^{\prime} \mathrm{N}$ latitude (Figure $1 \mathrm{a}$ ). The main stream in this reach is scattered and changeable, with rapid and frequent channel lateral migration. Bank erosion has often occurred in this reach because the bank soil is easily eroded and there has been a lack of bank revetment works (Figure 1c). The total length of this reach is $132.5 \mathrm{~km}$, with an average channel width of $8.5 \mathrm{~km}$ and an area of approximately $1107 \mathrm{~km}^{2}$. The sedimentation sections in this reach are successively named CS41 to CS68 from the lower to the upper reaches (Figure 1b), and the sections are surveyed twice a year to monitor the channel adjustments. The Xiaobeiganliu reach is usually divided into the upper, middle, and lower reaches. The upper reach is from LM (CS68) to Miaoqian (CS61), with a length of $42.5 \mathrm{~km}$, and it is characterized by severe channel lateral migration. The composition of the bed material is relatively thick, with the median diameter of bed material (D50) generally being between 0.2 and $0.3 \mathrm{~mm}$. The reach from Miaoqian (CS61) to Jiamakou (CS54) is defined as the middle reach, with a length of $30 \mathrm{~km}$. It is located at the top of the tertiary red soil anticline, so the channel is relatively stable. The lower reach is from Jiamakou (CS54) to TG (CS41), with a total length of $60 \mathrm{~km}$ and channel bed slope of 3\% [33].
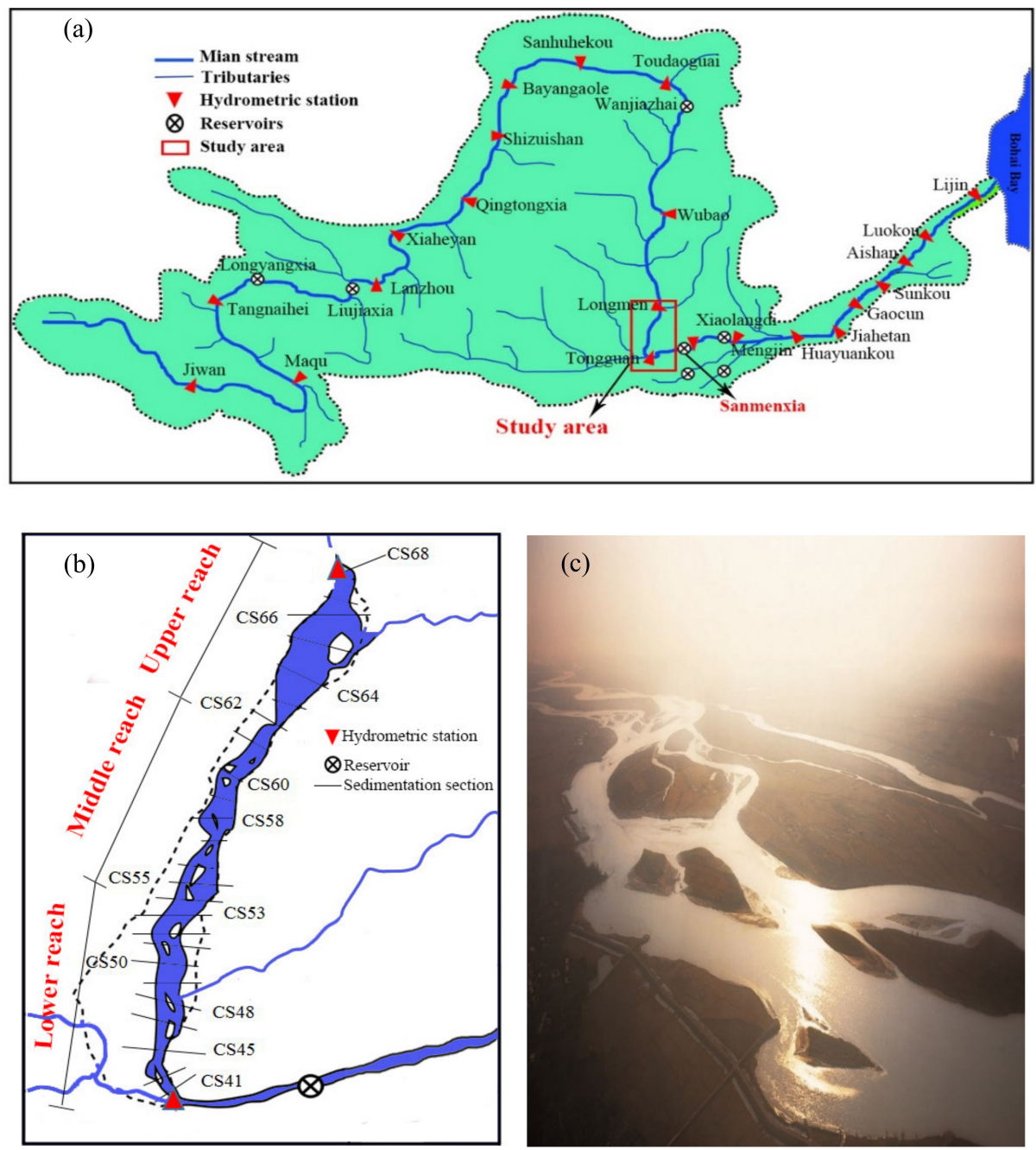

Figure 1. Overview of the study area: (a) Yellow River basin; (b) sketch of the Xiaobeiganliu reach; (c) photograph of the river channel. 
The LM station is the main upstream hydrometric station in the Xiaobeiganliu reach, and the flow and sediment regime at this station can represent the incoming flow and sediment conditions. The TG station is the main downstream hydrometric station, and the changes in TG elevation (the corresponding water level of TG station when the discharge equals $1000 \mathrm{~m}^{3} / \mathrm{s}$ ) can significantly influence the channel evolution of the Xiaobeiganliu reach. The Sanmenxia Reservoir, located approximately $113.5 \mathrm{~km}$ from the TG station, began operating in 1960 for flood control of the Yellow River. The Sanmenxia Reservoir has experienced several operation modes, and the TG elevation has been closely related to the continuous adjustment of the operation modes.

\subsection{Data Collection}

To investigate the incoming flow and sediment regime entering the Xiaobeiganliu reach, we collected hydrological data of LM station in 1960-2014 from the Yellow River Conservancy Commission of China (YRCC), and data included the daily mean discharge and sediment concentration. Figure 2 shows variations in the annual water discharge and sediment discharge at LM during hydrological years and flood seasons. From 1960 to 1973, the average annual water volume was approximately $310.8 \times 10^{8} \mathrm{~m}^{3} / \mathrm{yr}$, with an average annual sediment amount of $10.6 \times 10^{8}$ tons. In $1974-1985$, the average annual water volume did not change much, but the average annual sediment amount decreased to $6.5 \times 10^{8}$ tons due to soil and water conservation measures on the Loess Plateau. During the period from 1986 to 2002, the Longyangxia and Liujiaxia reservoirs on the upper Yellow River operated jointly. The average annual water volume entering the Xiaolangdi reach decreased to $197.2 \times 10^{8} \mathrm{~m}^{3} / \mathrm{yr}$ during this period, with the flood volume accounting for approximately $42 \%$. The average annual sediment amount decreased to $4.7 \times 10^{8}$ tons, with the flood amount accounting for $81 \%$. In 2003-2014, the average annual water volume did not change much, but the average annual sediment amount decreased dramatically to $2.1 \times 10^{8}$ tons because of the implementation of the water and soil conservation and the construction of various sediment trap dams in the Middle Yellow River.
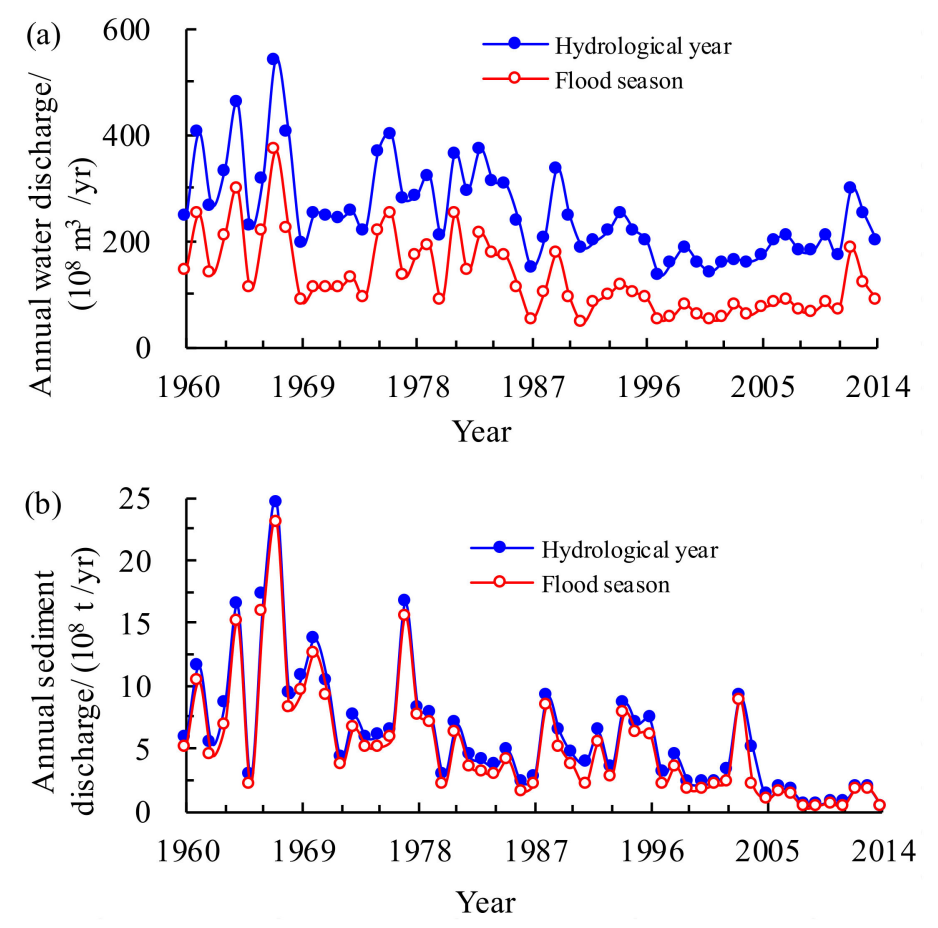

Figure 2. Temporal variations in the flow and sediment regime entering the Xiaobeiganliu reach: (a) annual water discharge; (b) annual sediment discharge. 
According to the observed data, the channel evolution process in the Xiaobeiganliu reach could be divided into four stages (Figure 3a): rapid deposition period (1960-1973), quasi-equilibrium period (1974-1985), continuous deposition period (1986-2002), and slow scour period (2003-2015), and the process was characterized by deposition in flood seasons and scouring in non-flood seasons. From 1960 to 2015, the total cumulative channel evolution volume in the Xiaobeiganliu reach was approximately $20.2 \times 10^{8} \mathrm{~m}^{3}$, with a cumulative deposition volume of $39.6 \times 10^{8} \mathrm{~m}^{3}$ in the flood season and a cumulative scour volume of $19.4 \times 10^{8} \mathrm{~m}^{3}$ in the non-flood season. The TG elevation is the erosion datum of the Xiaobeiganliu reach, which has an important influence on the fluvial processes of this reach. The post-flood TG elevations from 1960 to 2015 were also collected from the YRCC. Figure 3b shows that the TG elevation increased rapidly after the operation of the Sanmenxia Reservoir, and the elevation increased from $323.4 \mathrm{~m}$ in 1960 to $326.6 \mathrm{~m}$ in 1973. The TG elevation increased to 327.6 $\mathrm{m}$ in 1979 and then decreased to $326.6 \mathrm{~m}$ in 1985 during the quasi-equilibrium period. During the continuous deposition period, the TG elevation continued to increase from 327.2 to $328.8 \mathrm{~m}$. From 2003 to 2015, the Sanmenxia Reservoir carried out a prototype experiment, and the maximum operating water level in the non-flood season was controlled below $318 \mathrm{~m}$. During this period, the TG elevation decreased slowly, reaching $327.7 \mathrm{~m}$ in 2015.
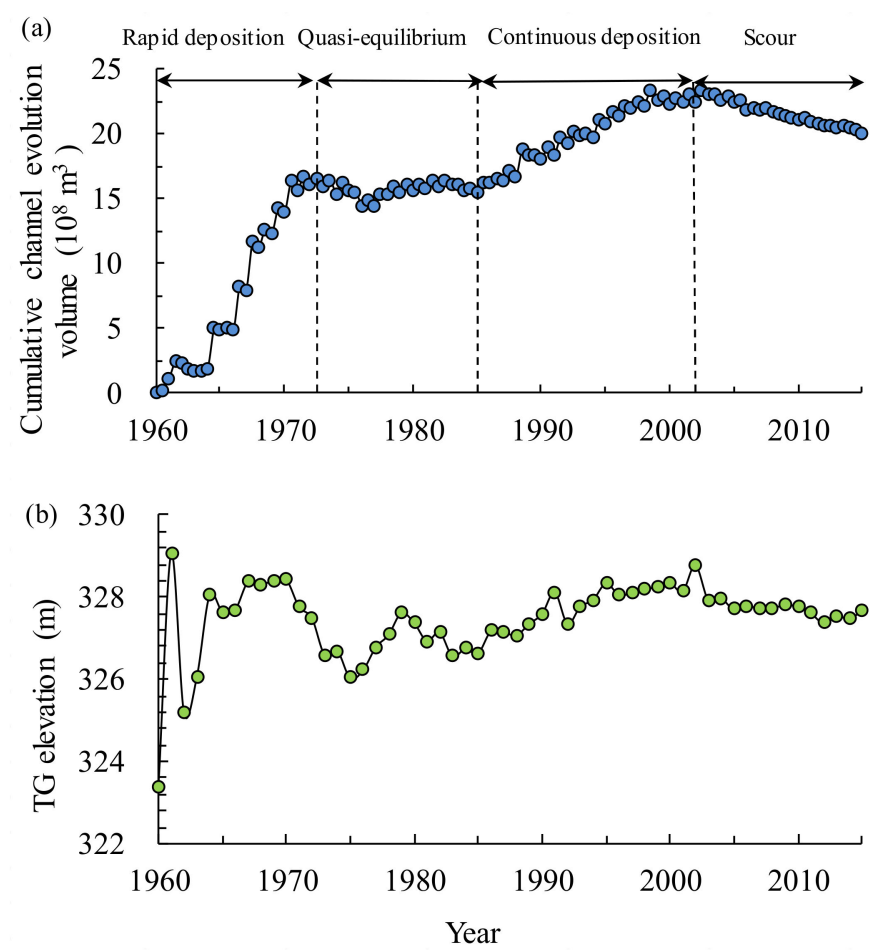

Figure 3. Variations in the cumulative channel evolution volume and the base level: (a) cumulative channel evolution volume; (b) Tongguan (TG) elevation.

Channel aggradation processes shrank the main channel significantly in the Xiaobeiganliu reach, which may bring potential hazards to the safety of flood control. It is more important to investigate the morphodynamic adjustments when it underwent channel aggradation processes than other periods. Therefore, we collected post-flood cross-sectional profiles at 25 sedimentation sections in the Xiaobeiganliu reach in 1986-2001 from the YRCC to investigate channel lateral migration during the continuous deposition period. 


\section{Methods}

\subsection{Determination of Parameters for Channel Lateral Migration}

Channel width adjustment was considered to be closely associated with channel lateral migration [31,34]. In this study, the parameter of bankfull width $\left(W_{i}\right)$ was used to investigate the channel width adjustment in the Xiaobeiganliu reach. In general, the lip-top level of an active floodplain at a section is termed the bankfull level, and the main-channel width between the two floodplain margins on left and right banks is defined as the bankfull width [16,35]. The thalweg migration distance $\left(D_{i}\right)$ was used to represent the magnitude of lateral migration in the current study, which was determined to be the lateral distance between two thalweg points in the previous and current years at one section [5]. For example, Figure 4 shows the post-flood cross-sectional profiles measured in 1986 and 1987 at the section of CS61. According to the method, the bankfull widths were determined to be $1435 \mathrm{~m}$ in 1986 and $1664 \mathrm{~m}$ in 1987, and the thalweg migration distance in the two years was determined to be $163 \mathrm{~m}$.

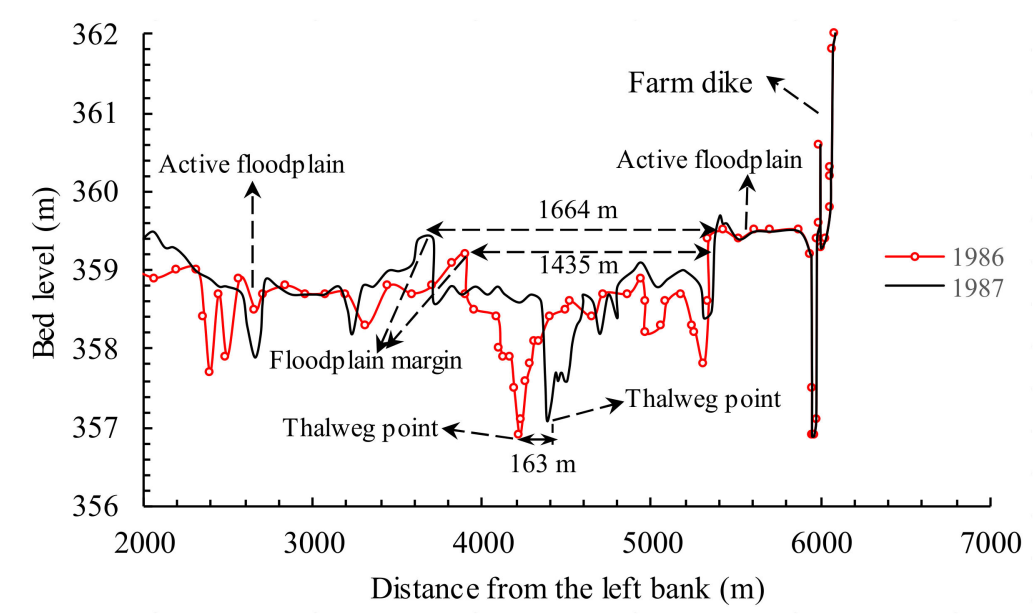

Figure 4. Determination of the bankfull width and thalweg migration distance at the section of CS61.

To investigate the channel lateral migration in the whole reach, a reach-averaged method proposed by Xia et al. [35] was used in the current study to calculate the reach-scale parameters. The reach-scale bankfull width and thalweg migration distance can be expressed as follows:

$$
\begin{gathered}
\bar{W}=\exp \left(\frac{1}{2 L} \sum_{i=1}^{N-1}\left(\ln W_{i+1}+\ln W_{i}\right) \times \Delta x\right) \\
\left.\Delta \bar{D}=\exp \left(\frac{1}{2 L} \sum_{i=1}^{N-1}\left(\ln \left|\Delta D_{i+1}\right|+\ln \left|\Delta D_{i}\right|\right) \times \Delta x\right)\right)
\end{gathered}
$$

where $L$ represents the channel length, and $N$ represents the number of cross sections. $\bar{W}$ and $\Delta \bar{D}$ represent the reach-scale bankfull width and thalweg migration distance, respectively. $W_{i+1}$ and $W_{i}$ represent the bankfull widths at the $(i+1)$ th and $i$ th sections, respectively. $\Delta D_{i+1}$ and $\Delta D_{i}$ are the thalweg migration distances at the $(i+1)$ th and $i$ th sections, respectively. $\Delta x$ is the longitudinal distance between adjacent sections. A dimensionless parameter of the lateral migration index $(M)$ was defined as $\bar{W} / \bar{D}$, which can be used to represent the lateral stability of the whole reach [5].

\subsection{Determination of Different Boundary Conditions}

The boundary conditions were divided into the upstream boundary condition, downstream boundary condition, and other boundary conditions. Previous studies have shown that antecedent flow 
and sediment regime characteristics can also significantly influence channel adjustments in alluvial rivers [35-37]. Therefore, the upstream boundary condition was represented by the previous n-year average water discharge $\left(\bar{Q}_{n}\right)$ and sediment concentration $\left(\bar{S}_{n}\right)$ at the LM station. The TG elevation is the base level of the Xiaobeiganliu reach; thus, the downstream boundary condition was represented by the variation in the annual TG elevation $(\Delta Z)$. In addition, the longitudinal channel slope and the elevation difference between the main channel and floodplain were determined to be other boundary conditions in this study. The elevation difference between the main channel and floodplain at a section is approximately equal to the cross-sectional bankfull depth, and the reach-scale bankfull depth $(\bar{H})$ can be written as:

$$
\bar{H}=\exp \left(\frac{1}{2 L} \sum_{i=1}^{N-1}\left(\ln H_{i+1}+\ln H_{i}\right) \times \Delta x\right)
$$

where $H_{i+1}$ and $H_{i}$ represent the bankfull depths at the $(i+1)$ th and $i$ th sections, respectively.

\section{Results and Discussion}

\subsection{Variation in Channel Bankfull Width}

The bankfull widths at sedimentation sections were determined in the Xiaobeiganliu reach in 1986-2001. The section-scale bankfull widths ranged between 600 and $3965 \mathrm{~m}$ in 2001, which indicated that the bankfull width varied significantly along the Xiaobeiganliu reach. Figure 5 shows the temporal variations in the bankfull width at the sections of CS61 and CS41 from 1986 to 2001. The figure shows that the bankfull width at the CS61 section fluctuated dramatically during this period, with the values varying between 1435 and $2719 \mathrm{~m}$. The maximum bankfull width occurred in 1989 because the mean water discharge in this year was greater than the discharges in other years. The bankfull width did not change much at the CS41 section, with the magnitude increasing from $411 \mathrm{~m}$ in 1986 to $601 \mathrm{~m}$ in 2001 . There are two main reasons for the spatial difference: one is that the bank soil at the CS61 section was easier to erode than that at the CS41 section; the other is that there was lack of enough river training works to limit river bank retreat at the CS61 section during this period. The reach-scale bankfull width of the Xiaobeiganliu reach was calculated using the Equation (1), as shown in Figure 5. The reach-scale bankfull width showed a decrease trend from $1866 \mathrm{~m}$ in 1986 to $1266 \mathrm{~m}$ in 2001, although bank retreat often occurred in the Xiaobeignaliu reach in the non-flood seasons. This result is mainly because hyperconcentrated floods with sediment concentrations greater than $300 \mathrm{~kg} / \mathrm{m}^{3}$ often occur in the flood season in this reach [38,39]. During a hyperconcentrated flood, water with very large amounts of sediment overtops the original bankfull level, and severe sediment deposition occurs on the floodplain marginal, with a new lip being formed, which causes the bankfull geometry to become narrower and deeper $[40,41]$. The decrease of bankfull width shrank the main channel in the Xiaobeiganliu reach, which may cause extreme high-water levels during flood seasons and bring potential hazards to the safety of people and levees.

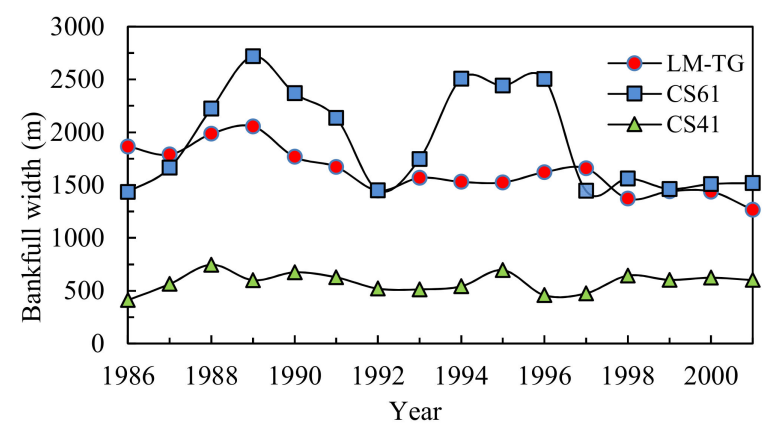

Figure 5. Temporal variations in the bankfull width at the typical sections of CS41 and CS61 and the reach-scale bankfull width in the Xiaobeiganliu reach. 


\subsection{Variation in Thalweg Migration Distance}

The section-scale thalweg migration distance was determined based on the repeatedly surveyed profiles of sedimentation sections in the Xiaobeiganliu reach in 1986-2001. Figure 6 shows the average, maximum, and minimum annual thalweg migration distances at 25 sedimentation sections along the Xiaobeiganliu reach. The section of CS63 had a maximum average thalweg migration distance of 1950 $\mathrm{m}$, with a maximum annual migration distance of $4290 \mathrm{~m}$ in 1998. The average thalweg migration distances at the sections of CS59, CS58, CS42, and CS41 were relatively small, with magnitudes less than $500 \mathrm{~m}$. This is because there were several natural nodes and river training works that can control the river regime at these sections. The cross-sectional thalweg migration distances in the upper reach were relatively greater than those in the middle and lower reaches. The results also indicate that thalweg migration distance varied greatly along the Xiaobeiganliu reach, and the variation tendency in one section cannot represent the tendency of the whole reach. Therefore, it is necessary to investigate the changes in the reach-scale thalweg migration distance.

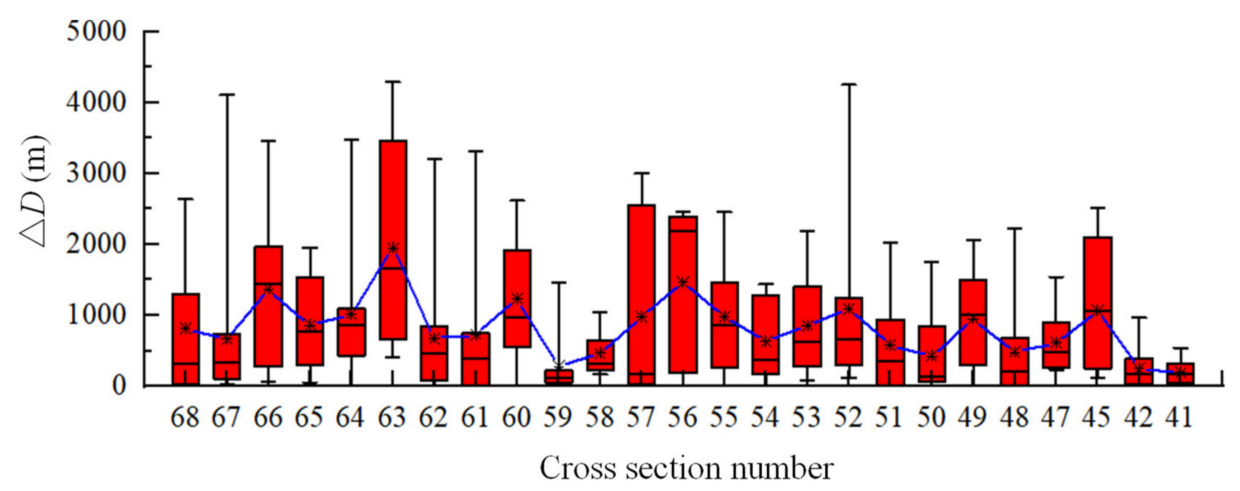

Figure 6. Spatial variations in section-scale thalweg migration distance along the Xiaobeiganliu reach.

Table 1 shows the reach-scale thalweg migration distances in the Xiaobeiganliu reach and three sub-reaches. The thalweg migration distance in the whole reach ranged from 210 to $707 \mathrm{~m}$, and the maximum thalweg migration occurred in 1991. Additionally, the average reach-scale thalweg migration distance in this reach was $385 \mathrm{~m}$. In the three sub-reaches, the LM-MQ reach had a maximum annual thalweg migration distance of $1603 \mathrm{~m}$, and the maximum annual thalweg migration distances were 930 and $510 \mathrm{~m}$ in the MQ-JMK and JMK-TG reaches, respectively. This result is because the middle reach is located at the top of the anticline of the Tertiary laterite layer, and the erosion resistance of the soil is stronger than that in the upper reach. In addition, some natural nodes and river training works in the middle and lower reaches played a significant role in restricting lateral migration. Thalweg migration in the Xiaobeiganliu reach was beneficial for the aquatic and riverine ecosystems, but the rapid migration significantly affected the stability of river channel and damage riparian hydraulic structures, which may threaten the safety of flood control.

\subsection{Effect of Upstream Boundary Conditions on Lateral Migration}

Conceptually, the hydraulic geometry of alluvial rivers is closely related to stream characteristics that vary with time [21]. The previous n-year average water discharge and sediment concentration increasingly appear to be useful parameters that can be used to explain the delayed response of channel adjustments of rivers $[5,37,42]$. To investigate the effect of upstream boundary conditions on lateral migration in the Xiaobeiganliu reach, the relationships were established between the lateral migration index and the parameters of $\bar{Q}_{n}$ and $\bar{S}_{n}$. The correlation degree between $M$ and $\bar{Q}_{n}$ reached the maximum value at $n=3$, and the correlation degree between the lateral migration index and $\bar{S}_{n}$ reached the maximum value at $n=4$. Figure 7 a shows the relationship between the lateral migration index and $\bar{Q}_{3}$, and it indicates that $M$ increased with an increase in $\bar{Q}_{3}$, with a correlation coefficient 
(R2) of 0.14 using a power function. The lateral migration index can also be expressed by a power function of $\bar{S}_{4}$, and the correlation coefficient was approximately 0.23 (Figure $7 \mathrm{~b}$ ).

Table 1. Reach-scale thalweg migration distance in the Xiaobeiganliu reach and three sub-reaches (m).

\begin{tabular}{ccccc}
\hline Year & LM-MQ Reach & MQ-JMK Reach & JMK-TG Reach & Xiaobeiganliu Reach \\
\hline 1987 & 470 & 147 & 189 & 230 \\
1988 & 536 & 225 & 281 & 319 \\
1989 & 1082 & 930 & 292 & 586 \\
1990 & 1603 & 350 & 347 & 543 \\
1991 & 1393 & 625 & 485 & 707 \\
1992 & 974 & 671 & 312 & 535 \\
1993 & 270 & 508 & 324 & 347 \\
1994 & 245 & 620 & 165 & 265 \\
1995 & 592 & 127 & 424 & 337 \\
1996 & 469 & 421 & 510 & 472 \\
1997 & 441 & 360 & 172 & 276 \\
1998 & 281 & 274 & 421 & 333 \\
1999 & 375 & 287 & 275 & 304 \\
2000 & 164 & 314 & 194 & 210 \\
2001 & 276 & 235 & 389 & 307 \\
\hline
\end{tabular}
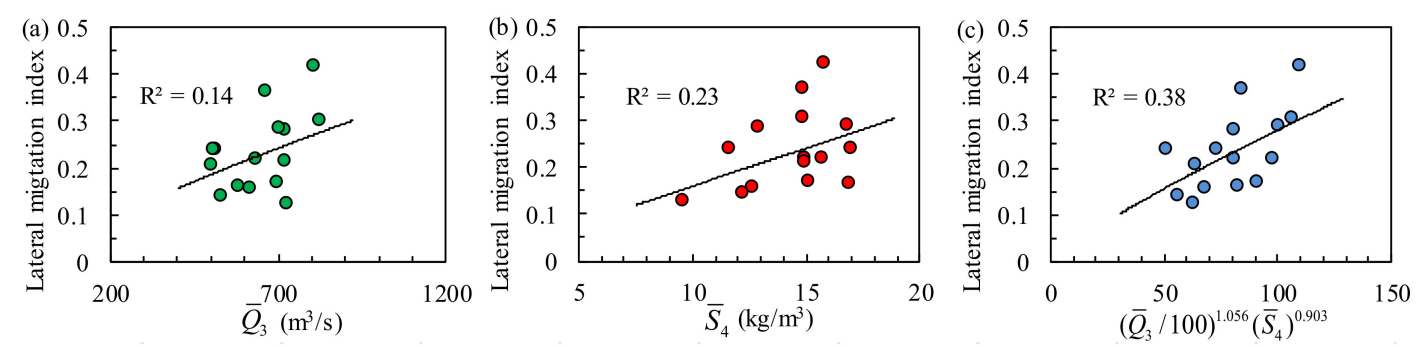

Figure 7. Relationships between the lateral migration index and the upstream boundary conditions in the Xiaobeiganliu reach: (a) previous 3-year average water discharge; (b) previous 4-year sediment concentration; (c) comprehensive parameter.

Taking into account the factors of the previous n-year water discharge and sediment concentration, an empirical relationship between $M$ and the two parameters was proposed, which can be expressed by:

$$
M=k\left(\bar{Q}_{3} / 100\right)^{\alpha}\left(\bar{S}_{4}\right)^{\beta}
$$

The data of previous 3-year average water discharge, previous 4-year sediment concentration and lateral migration index in 1986-2001 were used to conduct a multiple nonlinear regression based on Equation (4). This regression analysis was conducted using the Statistical Product and Service Solution software (SPSS), which is widely used to perform statistical analysis in the areas of natural sciences and technical sciences. The results show that the calibrated parameters of $k, \alpha$, and $\beta$ were equal to $0.003,1.056$, and 0.903 , respectively. Figure $7 \mathrm{c}$ shows the relationship between the lateral migration index and the comprehensive factor of $\left(\bar{Q}_{3} / 100\right)^{1.056}\left(\bar{S}_{4}\right)^{0.903}$, with a higher correlation coefficient of 0.38 . This result indicates that the upstream boundary conditions can affect the lateral migration in the Xiaolangdi reach, and the previous 3-year average water discharge and 4-year average sediment concentration were two key factors during this period.

\subsection{Effect of Downstream Boundary Conditions on Lateral Migration}

The base level is considered to be the key downstream boundary condition of an alluvial river, and the change in base level can lead to significant morphological adjustments [20]. Previous studies 
have shown that changes in TG elevation can greatly affect the aggradation and degradation processes in the Xiaobeiganliu reach $[43,44]$. To investigate the effect of downstream boundary conditions on lateral migration in the Xiaobeiganliu reach, the relationship was established between the channel lateral migration index and the variation in the annual TG elevation (Figure 8). It was found that the lateral migration index increased with an increase in $\Delta Z$, and the relationship could be written as $M=0.3607 \times(\Delta Z)^{0.2536}$, with a correlation coefficient of 0.62 . This result implied that the downstream boundary conditions played an important role in the channel lateral migration, and the drastic change in the annual TG elevation could greatly increase the channel lateral migration in the Xiaobeiganliu reach.

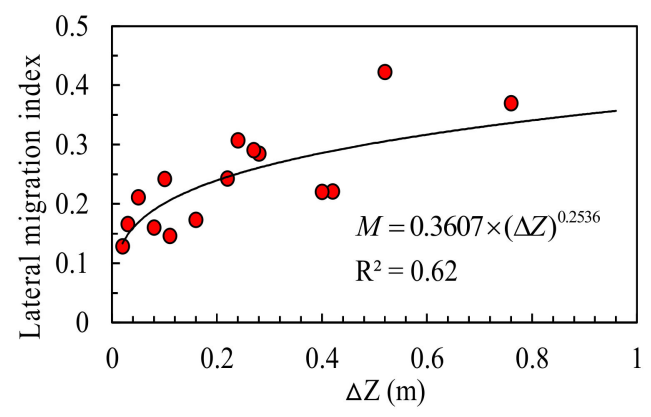

Figure 8. Relationship between the lateral migration index and the variation in TG elevation.

\subsection{Effect of Other Boundary Conditions on Lateral Migration}

Previous studies have shown that channel lateral migration is also affected by other boundary conditions, such as channel slope, bank soil composition, riparian vegetation, variables of planform geometry, and river training works $[29,31,35,45]$. Figure 9a shows the relationship between the lateral migration index and channel slope in the Xiaobeiganliu reach during the study period, and the data were relatively scattered. The correlation analysis of two variables was conducted using SPSS, and the result showed that the $p$-value equaled $0.523(>0.05)$, which indicated that there was no obvious relationship. Therefore, the channel slope had little effect on the lateral migration in the Xiaobeiganliu reach. Tian et al. [46] argued that the elevation difference between the floodplain and main channel may also influence lateral migration in wandering rivers, but the effect was not very significant. To investigate the effect of the elevation difference between the floodplain and main channel on lateral migration in the Xiaobeiganliu reach, Figure $9 \mathrm{~b}$ shows the relationship between the lateral migration index and $\bar{H}$. The correlation analysis of two variables was also conducted using SPSS, and the result showed that the $p$-value equaled 0.335 (>0.05), which implied there was no obvious relationship between the two variables. Therefore, the elevation difference between the floodplain and main channel had little effect on the lateral migration in the Xiaobeiganliu reach.
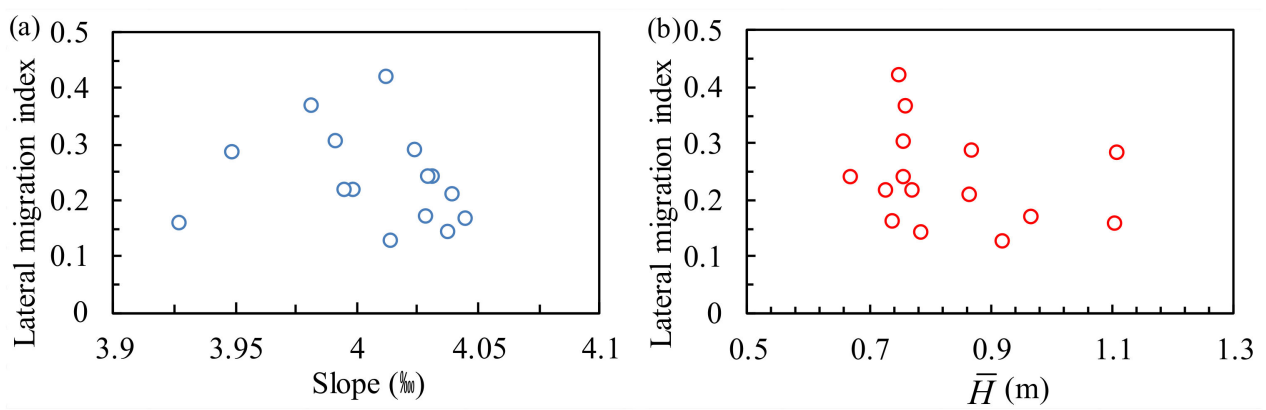

Figure 9. Relationships between the lateral migration index and other boundary conditions of (a) channel slope; (b) elevation difference between floodplain and main channel. 
Bank soil composition can also influence lateral migration in wandering rivers, and a lower clay content of bank soil usually results in more serious bank erosion [16]. Riparian vegetation can affect bank erosion to some extent, but it has little influence on long-term lateral migration distance [31,47]. For river training works, levee protection works have little influence on lateral migration because they seldom touch the main channel; however, the flow guide works can reduce the shifting of the thalweg [5,48]. Therefore, further detailed research on the effect of bank soil composition, riparian vegetation, and river training works must be conducted in the Xiaobeiganliu reach in the future.

\section{Conclusions}

The The Xiaobeiganliu reach is a typical wandering reach of the Middle Yellow River, which has frequent channel lateral migration. The variations in bankfull width and thalweg migration distance were calculated in the Xiaobeiganliu reach during the period between 1986 and 2001. In addition, the effects of different boundary conditions on lateral migration were investigated quantitatively. The conclusions obtained from this study are as follows:

(i) The reach-scale bankfull width in the Xiaobeiganliu reach showed a decreasing trend from 1866 to $1266 \mathrm{~m}$ due to the frequent hyperconcentrated flood events during 1986-2001. Thalweg migration distance varied greatly along the whole reach, and the reach-scale thalweg migration distance ranged from 210 to $707 \mathrm{~m}$. In the three sub-reaches, the LM-MQ reach had the maximum annual thalweg migration distance. The decrease of bankfull width and rapid thalweg migration may threaten the safety of flood control in the Middle Yellow River.

(ii) The upstream boundary conditions and downstream boundary conditions are the two key factors influencing lateral migration in the Xiaobeiganliu reach. An empirical relation was established between the lateral migration index and the comprehensive factor and was composed of the previous 3-year average water discharge and 4-year average sediment concentration. In addition, a power function was proposed between the lateral migration index and the variation in the annual TG elevation, which indicated that the change in the annual TG elevation could significantly increase the channel lateral migration in the Xiaobeiganliu reach. These empirical relations can be used to calculate and predict the processes of channel lateral migration in the Xiaobeiganliu reach. The methods and results can also be applied to investigate lateral migration in other wandering rivers, but the parameters in the relations should be calibrated according to the observed data of the study rivers.

Author Contributions: Funding acquisition \& Writing—original draft, J.L.; Formal analysis \& Software, Y.Z.; Writing-review \& editing, Q.J. All authors have read and agreed to the published version of the manuscript.

Funding: The study reported herein was supported by the High-level Scientific Research Foundation for the Introduction of Talent at Yangzhou University (Grant No. 5015/137011795).

Acknowledgments: The constructive suggestions of the anonymous reviewers and the $\mathrm{AE}$ are gratefully acknowledged.

Conflicts of Interest: The authors declare that there are no conflicts of interest.

\section{References}

1. Hooke, J.M. Magnitude and distribution of rates of river bank erosion. Earth Surf. Process Landf. 1980, 5, 143-150. [CrossRef]

2. Summerfield, M.A. Global Geomorphology; Longman Scientific \& Technical Harlow: White Plains, NY, USA, 1991.

3. Lawler, D.M. The measurement of river bank erosion and lateral channel change: A review. Earth Surf. Process Landf. 1993, 18, 777-821. [CrossRef]

4. Debnath, J.; Das, N.; Ahmed, I.; Bhowmik, M. Channel migration and its impact on land use/land cover using RS and GIS: A study on Khowai River of Tripura, North-East India. Egypt. J. Remote Sens. Space Sci. 2017, 20, 197-210. [CrossRef]

5. Li, J.; Xia, J.Q.; Zhou, M.R.; Deng, S.; Zhang, X. Variation in reach-scale thalweg-migration intensity in a braided reach of the lower Yellow River in 1986-2015. Earth Surf. Process Landf. 2017, 42, 1952-1962. [CrossRef] 
6. Shields, F.D., Jr.; Milhous, R.T. Sediment and aquatic habitat in river systems. Final report, American Society of Civil Engineers Task Committee on Sediment Transport and Aquatic Habitat. J. Hydraul. Eng. 1992, 118, 669-687.

7. Bunn, S.E.; Arthington, A.H. Basic principles and ecological consequences of altered flow regimes for aquatic biodiversity. Environ. Manag. 2002, 30, 492-507. [CrossRef]

8. Florsheim, J.L.; Mount, J.F.; Chin, A. Bank erosion as a desirable attribute of rivers. BioScience 2008, 58, 519-529. [CrossRef]

9. Richard, G.A.; Julien, P.Y.; Baird, D.C. Case Study: Modeling the Lateral Mobility of the Rio Grande below Cochiti Dam, New Mexico. J. Hydraul. Eng. 2005, 131, 931-941. [CrossRef]

10. Williams, R.D.; Bangen, S.; Gillies, E.; Kramer, N.; Moir, H.; Wheaton, J. Let the river erode! Enabling lateral migration increases geomorphic unit diversity. Sci. Total Environ. 2020, 715, 136817. [CrossRef]

11. Shields, F.D., Jr.; Simon, A.; Steffen, L.J. Reservoir effects on downstream river channel migration. Environ. Conserv. 2000, 27, 54-66. [CrossRef]

12. Yeh, P.H.; Park, N.; Chang, K.A.; Briaud, L.J. Prediction of time-dependent channel meander migration based on large-scale laboratory experiments. J. Hydraul. Res. 2011, 49, 617-629. [CrossRef]

13. Ghinassi, M.; Nemec, W.; Aldinucci, M.; Nehyba, S.; Özaksoy, V.; Fidolini, F. Plan-form evolution of ancient meandering rivers reconstructed from longitudinal outcrop sections. Sedimentology 2014, 61, 952-977. [CrossRef]

14. Alber, A.; Piégay, H. Characterizing and modelling river channel migration rates at a regional scale: Case study of south-east France. J. Environ. Manag. 2017, 202, 479-493. [CrossRef] [PubMed]

15. Legg, N.T.; Olson, P.L. Channel Migration Processes and Patterns in Western Washington. A Synthesis for Floodplain Management and Restoration; Washington State Department of Ecology: Olympia, WA, USA, 2014.

16. Xia, J.Q.; Li, J.; Carling, P.A.; Zhou, M.; Zhang, X. Dynamic adjustments in bankfull width of a braided reach. Proc. Inst. Civil Eng. Water Manag. 2019, 172, 207-216. [CrossRef]

17. Gogoi, C.; Goswami, D.C. A Study on bank erosion and bank line migration pattern of the Subansiri river in Assam using remote sensing and GIS technology. Int. J. Eng. Sci. 2013, 2, 1-6.

18. Nelson, N.C.; Erwin, S.O.; Schmidt, J.C. Spatial and temporal patterns in channel change on the Snake River downstream from Jackson Lake dam, Wyoming. Geomorphology 2013, 200, 132-142. [CrossRef]

19. Sun, J.; Lin, B.; Kuang, H. Numerical modelling of channel migration with application to laboratory rivers. Int. J. Sediment Res. 2015, 30, 13-27. [CrossRef]

20. Schumm, S.A. River response to base level change: Implications for sequence stratigraphy. J. Geol. 1993, 101, 279-294. [CrossRef]

21. Julien, P.Y. River Mechanics; Cambridge University Press: London, UK, 2002.

22. Lawler, D.M.; Grove, J.R.; Couperthwaite, J.S.; Leeks, G.J.L. Downstream change in river bank erosion rates in the Swale-Ouse system, Northern England. Hydrol. Process. 1999, 13, 977-992. [CrossRef]

23. Wang, Y.Z.; Xia, J.Q.; Zhou, M.R.; Jiang, Q.R. Characteristics of main channel migration in the braided reach of the Lower Yellow River after the Xiaolangdi Reservoir operation. Adv. Water Sci. 2019, 30, 198-209. (In Chinese)

24. Begin, Z.B.; Meyer, D.F.; Schumm, S.A. Development of longitudinal profiles of alluvial channels in response to base-level lowering. Earth Surf. Process. Landf. 1981, 6, 49-68. [CrossRef]

25. Edwards, B.L.; Keim, R.F.; Johnson, E.L.; Hupp, C.R.; Marre, S.; King, S.L. Geomorphic adjustment to hydrologic modifications along a meandering river: Implications for surface flooding on a floodplain. Geomorphology 2016, 269, 149-159. [CrossRef]

26. Vachtman, D.; Laronne, J.B. Hydraulic geometry of cohesive channels undergoing base level drop. Geomorphology 2013, 197, 76-84. [CrossRef]

27. Lin, F.F.; Xia, J.Q.; Zhou, M.R.; Deng, S. Morphodynamic evolution in a meandering reach of the Middle Yangtze River under upstream and downstream controls. Prog. Phys. Geogr. 2019, 43, 544-560. [CrossRef]

28. Shi, C.X.; Zhou, Y.Y.; Liu, X.F. River base level change in mouth channel evolution: The case of the Yellow River delta, China. Catena 2019, 183, 104193. [CrossRef]

29. Odgaard, A.J. Streambank erosion along two rivers in Iowa. Water Resour. Res. 1987, 23, 1225-1236. [CrossRef]

30. Beeson, C.E.; Doyle, P.F. Comparison of bank erosion at vegetated and non-vegetated channel bends. Water Resour. Bull. 1995, 31, 983-990. [CrossRef] 
31. Nanson, G.C.; Hickin, E.J. A statistical analysis of bank erosion and channel migration in western Canada. Geol. Soc. Am. Bull. 1986, 97, 497-504. [CrossRef]

32. Guo, X.J.; Hou, S.Z.; Wang, P. The relationship between changes of the main streamline and flow and sediment regime in Xiaobeiganliu reach of Yellow River. China Rural Water Hydropower 2018, 11, 98-102. (In Chinese)

33. Yellow River Xiaobeiganliu Shanxi Division. Xiaobeiganliu in Yellow River; The Yellow River Water Conservancy Press: Zhengzhou, China, 2002. (In Chinese)

34. Brice, J.C. Stream Channel Stability Assessment, Final Report; Report FHWA/RD-82/021; Federal Highway Administration, US Department of Transportation: Washington, DC, USA, 1982.

35. Xia, J.Q.; Li, X.J.; Li, T.; Zhang, X.L.; Zong, Q.L. Response of reach-scale bankfull channel geometry in the Lower Yellow River to the altered flow and sediment regime. Geomorphology 2014, 213, 255-265. [CrossRef]

36. Wu, B.S.; Xia, J.Q.; Fu, X.D.; Zhang, Y.; Wang, G. Effect of altered flow regime on bankfull area of the lower Yellow River, China. Earth Surf. Process. Landf. 2008, 33, 1585-1601. [CrossRef]

37. Wu, B.S.; Zheng, S.; Thorne, C.R. A general framework for using the rate law to simulate morphological response to disturbance in the fluvial system. Prog. Phys. Geogr. 2012, 36, 575-597. [CrossRef]

38. Shu, A.P.; Fei, X.J. Sediment transport capacity of hyperconcentrated flow. Sci. China Ser. G Phys. Mech. Astron. 2008, 51, 961-975. [CrossRef]

39. Van Maren, D.S.; Winterwerp, J.C.; Wang, Z.Y.; Pu, Q. Suspended sediment dynamics and morphodynamics in the Yellow River, China. Sedimentology 2009, 56, 785-806. [CrossRef]

40. Wang, Z.Y.; Qi, P.; Melching, C.S. Fluvial hydraulics of hyperconcentrated floods in Chinese rivers. Earth Surf. Process. Landf. 2009, 34, 981-993. [CrossRef]

41. Li, J.; Xia, J.Q.; Zhou, M.R.; Deng, S.; Wang, Z. Channel geometry adjustments in response to hyperconcentrated floods in a braided reach of the Lower Yellow River. Prog. Phys. Geogr. 2018, 42, 352-368. [CrossRef]

42. Lyu, Y.W.; Zheng, S.; Tan, G.M.; Shu, C.; Han, Q. Morphodynamic adjustments in the Yichang-Chenglingji Reach of the Middle Yangtze River since the operation of the Three Gorges Project. Catena 2019, 172, 274-284. [CrossRef]

43. Zheng, S.; Wu, B.S. Simulation of sedimentation processes of the Xiaobeiganliu reach of the Yellow River and the lower Wei River. J. Hydraul. Eng. 2014, 45, 150-162. (In Chinese)

44. Shao, W.W.; Wu, B.S.; Wang, Y.J.; Zhang, R.Y. Simulation of sedimentation processes in dry and wet seasons in the Xiaobeiganliu reach of the Yellow River. Acta Geogr. Sin. 2018, 73, 880-892. (In Chinese)

45. Harrison, L.R.; Legleiter, C.J.; Wydzga, M.A.; Dunne, T. Channel dynamics and habitat development in a meandering, gravel bed river. Water Resour. Res. 2011, 47, 1-21. [CrossRef]

46. Tian, S.M.; Wang, W.H.; Xie, B.F.; Zhang, M. Fluvial processes of the downstream reaches of the reservoirs in the Lower Yellow River. J. Geogr. Sci. 2016, 26, 1321-1336. [CrossRef]

47. Constantine, C. Quantifying the connections between flow, bar deposition, and meander migration in large gravel-bed rivers. Ph.D. Thesis, University of California, Santa Barbara, CA, USA, 2006.

48. Wu, B.S.; Wang, G.Q.; Ma, J.M.; Zhang, R. Case study: River training and its effects on fluvial processes in the Lower Yellow River, China. J. Hydraul. Eng. 2005, 131, 85-96. [CrossRef]

(C) 2020 by the authors. Licensee MDPI, Basel, Switzerland. This article is an open access article distributed under the terms and conditions of the Creative Commons Attribution (CC BY) license (http://creativecommons.org/licenses/by/4.0/). 